\title{
Sylwia Bielawska
}

Państwowa Wyższa Szkoła Zawodowa

im. Angelusa Silesiusa w Wałbrzychu

e-mail: s.bielawska@um.walbrzych.pl

\section{Wampiry, demony, upadłe anioły... Analiza rynku książki dla młodzieży (2010-2017) - wybrane aspekty}

\section{DOI: http://dx.doi.org/10.18778/0860-7435.28.01}

\begin{abstract}
Abstrakt: W świecie nastolatków, od lat rządzonym przez Facebooka, Twittera, Instagram i inne media społecznościowe, stałe kontakty z czytaniem i książkami są często tylko przypadkowe, sprowadzone do czytania lektur w szkole, czego dowodem są niepokojące badania czytelnictwa w tej grupie wiekowej. Z drugiej strony jednak młodzi fani Internetu i gier komputerowych, zaintrygowani atrakcyjnymi książkami, są w stanie dokonywać świadomych wyborów czytelniczych i angażować się w czytelnictwo. Przyjmując powyższe założenie, podjęto próbę analizy rynku książki dla nastolatków w latach 2010-2017. Na podstawie danych przekazanych przez Główny Urząd Statystyczny, Bibliotekę Narodową, Bibliotekę Analiz i Polską Izbę Książek, przeprowadzono ilościową i jakościową analizę tego najbardziej wymagającego, według Łukasza Gołębiewskiego i Pawła Waszczyka rynku książki, zidentyfikowano mechanizmy rządzące tym sektorem, a także wskazano możliwe działania naprawcze mające na celu stymulowanie i kształtowanie trwałych zainteresowań czytelniczych wśród młodzieży.
\end{abstract}

Słowa kluczowe: rynek książki, literatura dla młodzieży, ilościowa i jakościowa analiza rynku książki dla młodzieży 


\section{Wprowadzenie}

Jeżeli, jak podają Lukasz Gołębiewski i Paweł Waszczyk, sektor książek dla młodzieży to „najbardziej wymagający sektor księgarski w Polsce” (2015, s. 161), to z obserwacji tej powinna wynikać także sugestia, że rynek książki dla młodzieży jest $z$ pewnych względów intrygujący. Z tego właśnie powodu $\mathrm{w}$ artykule podjęto próbę ukazania charakterystycznych dla tego rynku trendów zaznaczających się w okresie 2010-2017. W tekście oprócz omówienia zagadnień teoretycznych przeprowadzono analizę rynku wykorzystując wskaźniki charakteryzujące jego rozwój i potencjał ekonomiczno-społeczny: wartość rynku, przychody ze sprzedaży książek, repertuar (wydane tytuły, nakłady). Podjęto także próbę identyfikacji i oceny wybranych zjawisk tego segmentu rynku, a także scharakteryzowano pokrótce rynek e-książki i audiobooki oraz formy promocji i stan czytelnictwa młodzieży.

Ramy czasowe badanego zagadnienia wyznaczone sa z jednej strony przez rok 2010, zamykający symbolicznie dekadę niezwykłego ożywienia na rynku książki młodzieżowej, zdeterminowanego przez „najbardziej elektryzujące newsy: wyraźne mody, odkrycia przekuwane na setki tysięcy sprzedanych egzemplarzy, nowe gwiazdy" (Zając, 2014, s. 1), z drugiej przez rok 2017, z którego pochodzą ostatnie, aktualne raporty dotyczące rynku książki. Spróbujemy zrekonstruować realia rynku po czasach ogromnej popularności sagi o Harrym Potterze, kiedy to przez półki z literatura młodzieżową przeszło „prawdziwe trzęsienie ziemi” (Gołębiewski, Frołow \& Waszczyk, 2010, s. 100). Szczególnie interesująca wydaje się kwestia znalezienia odpowiedzi na pytanie, czy wydawcom udało się wypełnić lukę w ofercie wydawniczej i jak sobie poradzili z tym niełatwym zadaniem skoro, jak twierdza analitycy rynku, „w segmencie książki dla młodzieży nastapiła wyraźna posucha, brakuje nowych pomysłów i bestsellerów" (Gołębiewski, Frołow \& Waszczyk, 2010, s. 96).

$\mathrm{Na}$ koniec pewna uwaga porządkująca. Ze względu na ograniczoną dostępność niektórych danych statystycznych (np. odnośnie do wielkości nakładu lub wartości tej części rynku książki) przytaczane i analizowane dane sa niepełne i pochodzą z różnych źródeł i okresów. Ich niepełny charakter oraz brak reprezentatywności uniemożliwia ustalenie rzeczywistych wartości całego rynkowego potencjału, zwłaszcza że instytucje przygotowujące odpowiednie raporty (Biblioteka Narodowa, Biblioteka Analiz, Instytut Książki) otwarcie przyznają, iź świadomie rezygnuja z podawania części danych z powodu trudności związanych z uzyskaniem pełnej i wiarygodnej informacji ${ }^{1}$.

\footnotetext{
${ }^{1}$ Biblioteka Narodowa w Uwagach wstęnych w „Ruchu Wydawniczym w Liczbach” otwarcie przyznaje, że wydawcy lekceważą zapisy ustawy o egzemplarzu obowiązkowym w związku z czym obliczenia oparte na przekazanych drukach moga być niepełne. Z kolei Biblioteka
} 
Kolejną trudnością w pozyskiwaniu danych są nieustanne zmiany w ich kategoryzacji funkcjonalnej. Te same dane w analizowanym okresie opisywane były za pomocą różnych wskaźników. Ponadto od 2013 r. pojawiły się w raportach nowe typologie, które w założeniu miały lepiej oddać bogactwo form publikacji na rynku wydawniczym, ale w rezultacie porzucono niektóre istotne wskaźniki, co uniemożliwia precyzyjniejsze i dokładniejsze scharakteryzowanie rynku książki młodzieżowej.

W niniejszej analizie dane statystyczne dotyczące produkcji literatury dla młodzieży pochodzą z corocznego, unikatowego raportu o produkcji wydawniczej w Polsce, który przygotowuje Biblioteka Narodowa (,Ruch Wydawniczy w Liczbach”, 2010-2017). Obliczenia prezentowane w raporcie dotycza produkcji wydawniczej w danym roku i obejmują te publikacje, które zostały wydane na terenie Rzeczypospolitej Polskiej i zostały - zgodnie z obowiązujacym prawem - przekazane jako egzemplarze obowiązkowe do Biblioteki Narodowej. Dodać należy, że publikacje popularnonaukowe dla tej grupy odbiorców zostały włączone do pozostałych publikacji popularnonaukowych i nie są tematem naszej analizy ${ }^{2}$.

\section{Zagadnienia definicyjne}

L Najbardziej adekwatną definicję opisująca przedmiot niniejszych badań stworzył Marek Tobera, w którego ujęciu rynek książki to:

ogół działań prowadzonych w ramach funkcjonowania tego fragmentu gospodarki, który obejmuje sprawy dotyczące wydania, dystrybucji, sprzedaży hurtowej i detalicznej książek, aktywności firm i innych instytucji (podmiotów) zaangażowanych w tego typu przedsięwzięcia oraz kwestii wpływajacych na podaż i popyt w tej dziedzinie (2008, s. 38).

Definicja ta, podkreślająca wyraźnie ekonomiczny charakter rynku, wydaje się być najodpowiedniejsza dla naszych dalszych rozważań, stąd w niniejszym tekście będziemy używać terminu rynek ksiażki porzucając niejako określenie ruch wydawniczy rozpowszechnione przez Bibliotekę Narodową.

Warto dodać, że interesować nas będzie jedynie oferta wydawnicza skierowana do młodzieży, a zatem osób pomiędzy 12 a 18 rokiem życia, zwanych

\footnotetext{
Analiz swoje szacunki opiera na badaniach ankietowych wydawców, które uzupełnia wynikami z „Monitora Gospodarczego”, aktami pozostającymi w dyspozycji sądów gospodarczych oraz z wszelkiego rodzaju innych dokumentów o charakterze sprawozdawczo-finansowym.

${ }^{2} \mathrm{Na}$ marginesie naszych rozważań pozostawimy też kwestię zarzutów o ewentualne $10-20 \%$ niedoszacowanie w porównaniu z danymi publikowanymi przez Bibliotekę Analiz (Gołębiewski, Frołow \& Waszczyk, 2010, s. 58-59).
} 
Young Adult (Peterson, 2018). Analizie poddamy produkcję wydawnicza przygotowaną dla współczesnej młodzieży żyącej w świecie zdominowanym przez mass media, które „stały się najpotężniejszym instrumentem kształtowania systemu wartości" (Sullivan, 1987, s. 57-58). W prowadzonych analizach niezwykle ważną kwestią stanie się próba uzyskania odpowiedzi na pytanie, czy rynek książki jest w stanie przygotować atrakcyjną ofertę dla współczesnego ,globalnego nastolatka”, przedstawiciela pokolenia Y, którego skomercjalizowaną osobowość kształtują nie wartości narodowe i państwowe, ale kultura popularna i ideologia konsumpcji, a socjalizuje go komputer (Melosik, 2003, s. 26-27). Na marginesie naszych rozważań pozostawimy więc segment książki dziecięcej, gdyż ten fragment rynku charakteryzuje się odmiennymi cechami. Zaledwie w kilku przypadkach, z uwagi na zasady przyjęte przez pracowników Zakładu Statystyki Wydawnictw BN, będziemy posługiwać się kategorią ogólną ,literatura dla dzieci i młodzieży”, gdyż w wielu interesujących aspektach nie dokonano podziału tych dwóch kategorii.

Konieczne w tym miejscu wydaje się przypomnienie, że do kategorii literatury dla młodzieży

zaliczamy jedynie przeznaczone dla nastolatków teksty literackie [...]. Należy podkreślić, że do omawianej kategorii należą wszystkie utwory, które aktualnie postrzegane są jako interesujące przede wszystkim dla niedorosłych odbiorców, czyli zarówno takie, które z założenia przeznaczone były dla młodych czytelników, jak i takie, które powstały raczej z myślą o czytelnikach dorosłych, ale w praktyce, lub po pewnym czasie zaczęły przyciagać młodą publiczność, co spowodowało nadanie im etykiety literatury młodzieżowej przez czytelników, wydawców oraz księgarzy i bibliotekarzy („Ruch Wydawniczy w Liczbach”, 2016, s. 28).

\section{Produkcja wydawnicza dla młodzieży w latach 2010-2017}

L Literatura dla młodzieży mieści się w obrębie zbioru książek literackich, do którego zalicza się też literatura piękna, literatura romansowo-obyczajowa, sensacyjno-kryminalna, fantastyczna, komiksy, humor i anegdota ${ }^{3}$. Stanowi ona zaledwie $1 \%$ zbioru wszystkich wydanych tytułów zarejestrowanych w bibliografii narodowej w interesujacych nas latach oraz $4 \% \mathrm{w}$ ramach całego zbioru tekstów literackich („Ruch Wydawniczy w Liczbach”, 2017, s. 27). Udział książek dla nastolatków w rynku książek jest zatem nikły, a przy tym niestabilny ,jak gdyby siła zjawisk zapoczątkowanych pojawieniem się powie-

\footnotetext{
${ }^{3}$ Dopiero od 2013 r. BN dzieli utwory literackie na większą liczbę kategorii, w tym wyróżnia m.in. literaturę młodzieżową i publikacje dla dzieci, co pozwala na dokładniejszą analizę.
} 
ści Rowling zaczynała się powoli wyczerpywać” („Ruch Wydawniczy w Liczbach", 2015, s. 35).

Zacznijmy od szacunków wartości rynku książek dla dzieci i młodzieży oraz analizy nakładów, na podstawie danych Biblioteki Analiz, które zawiera tabela nr 1.

Tab. 1. Wartość rynku książki dla dzieci i młodzieży w latach 2010-2017

\begin{tabular}{|c|c|c|c|c|}
\hline Rok & $\begin{array}{c}\text { Wartość rynku } \\
\mathbf{w} \text { mln zł }\end{array}$ & $\begin{array}{c}\text { Nakład łączny } \\
\text { w mln egzemplarzy }\end{array}$ & $\begin{array}{c}\text { Średni nakład } \\
\text { w egzemplarzach }\end{array}$ & $\begin{array}{c}\text { Średnia cena } \\
\text { zbytu u wydawcy }\end{array}$ \\
\hline 2010 & $222 /-1,76 \%$ & 19,1 & 5841 & $14,92 \mathrm{zł}$ \\
\hline 2011 & $161 /-27,4 \%$ & 14,3 & 4256 & $15,38 \mathrm{zł}$ \\
\hline 2012 & $152 /-5,6 \%$ & 11,5 & 3495 & $17,83 \mathrm{zł}$ \\
\hline 2013 & $159 /+4,6 \%$ & 13,1 & 3250 & $16,03 \mathrm{zł}$ \\
\hline 2014 & $168 /+5,6 \%$ & 12,6 & 3158 & $15,08 \mathrm{zł}$ \\
\hline $2015 *$ & $174 /+3,4 \%$ & b.d. & 2798 & $23,70 \mathrm{zł}$ \\
\hline 2016 & $170 /-2 \%$ & b.d. & 2435 & $24,20 \mathrm{zł}$ \\
\hline 2017 & b.d. & b.d. & b.d. & b.d. \\
\hline
\end{tabular}

* dane z lat 2015-2017 obliczone według średnich dla całego rynku książki dlatego można je traktować tylko orientacyjnie

Źródło: opracowanie własne na podstawie Rynek ksiażki w Polsce 2010-2017. Wydawnictwa.

Najboleśniejszy spadek odnotowano w fatalnym dla całego polskiego rynku książki 2011 r., w którym zanotowano aż o 27,4\% spadek wartości rynku w stosunku do wcześniejszego roku, choć luke po potteromaniakach wypełniła „wampirza saga” Stephenie Meyer, której łączna sprzedaż przekroczyła w 2010 r. 383 tys. egz. (Gołębiewski, Frołow \& Waszczyk, 2011, s. 124). Spadek wartości rynku możemy wiązać ze swoistym zamieszaniem w sferze dystrybucji, jakie nastapiło po wprowadzeniu od 1 stycznia 2011 r. okresu przejściowego, a od 1 kwietnia stałej 5\% stawki podatku VAT na książki drukowane. Niektórzy wydawcy, z uwagi na niejasność i rozbieżne komentarze ekonomistów, publikowali mniej nowości (szacuje się, że ok. 30\%), a najwięksi detaliści stacjonarni (w tym m.in. Empik i Matras), jak i czołowi sprzedawcy internetowi (np. Merlin.pl) czy ogólnoasortymentowe dyskonty i markety, czasowo ograniczyli zamówienia. Nie dziwi zatem spadek przychodów, zwłaszcza że zabrakło nowych atrakcyjnych pomysłów czy bestsellerów, 
a „miejsce kilku hitów o kilkutysięcznej sprzedaży zastąiła nieco większa grupa tytułów, które rozchodzą się w nakładzie powyżej 20 tys. egz., następnie bardzo liczna grupa tytułów, których sprzedaż oscyluje nieco poniżej tej liczby, a także w granicach od blisko 10 do 15 tys. egz." (Gołębiewski, Frołow \& Waszczyk, 2011, s. 131). Można uznać, że nastąpiła pewna normalizacja, gdyż w naturalny sposób poskromiono „oczekiwania finansowe pokładane w książkach dla niedorosłych, rozbuchane nadmiernie przez prawie dekadę bestsellerów i fajerwerków" (Zając, 2012, s. 4).

Nic zatem dziwnego, że dopiero w 2013 r. rynek zaczyna odnotowywać odrobinę lepszą koniunkturę, choć znawcy nazywali to zaledwie „powrotem do pewnej przeciętności" (Zając, 2014, s. 1). Wzrost ma raczej symboliczny charakter i nie jest wynikiem poprawy koniunktury, ale pojawienia się w sprzedaży kilku nowych bestsellerów autorstwa Suzanne Collins (Igraysska śmierci, $W$ pierścieniu ognia, Kosogłos wydanych przez Media Rodzina), Christophera Paoliniego (cykl Driedzictwo wydawnictwa Mag), Ricka Riordana (cykl Percy Jackson i Bogowie Olimpijscy opublikowany przez Galerię Książki), Johna Flanagana (seria Zwiadowcy wydawnictwa Jaguar).

Zauważalne w kolejnych latach wzrosty, choć nie należą do najwyższych, są jednak wystarczające, aby przeważyć spadki z lat 2011-2013 i udowodnić, że były one jedynie chwilowym zaburzeniem w stałym trendzie wzrostowym obserwowanym od lat 90 . XX w. Decydujące znaczenie maja tu z pewnościa przemiany kulturowe, a zwłaszcza coraz bogatsze formy rozrywki, które skutecznie odciagają młodzież od książek.

Konstatacje, jakie się rodzą po analizie wysokości nakładów i wartości rynku, nie powinny być zaskoczeniem, gdyż sa powtórzeniem znanej marketingowej prawdy, że po fali ożywienia w całym segmencie rynku książki dla młodych czytelników wydawcy nie zdołali utrzymać tendencji wzrastającej z powodu braku atrakcyjnej oferty, w wyniku czego rynek książki „znacząco skurczył się" (Zając, 2012, s. 1).

Nie dziwi także utrzymująca się od lat tendencja do coraz mniejszych nakładów przy stałym wzroście liczby tytułów (patrz rys. 1). Przyczyną takiej sytuacji jest bez wątpienia spadek średnich nakładów wynikający ze wzrostu elastyczności w zakresie planowania i zarządzania produkcją wydawniczą oraz zmieniających się współczesnych technik wydawniczych (coraz więcej wydawców decyduje się na nakład inicjalny oraz dodruk w kilku rozsądnych częściach uzależniony od aktualnych potrzeb). 
Rys. 1. Liczba wydanych tytułów dla młodzieży w latach 2010-2017

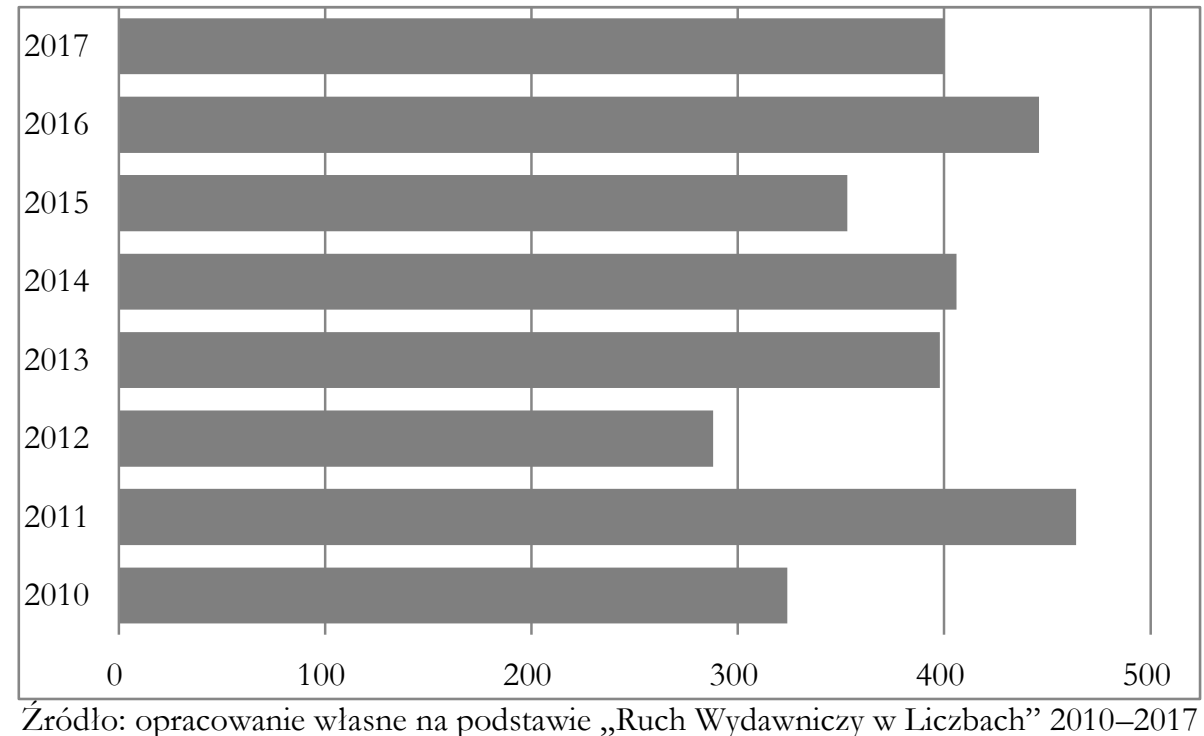

Zarówno spadki, jak i wzrosty, które zauważamy w zakresie liczby wydanych tytułów nie mają charakteru dramatycznego, raczej mamy do czynienia z sinusoidalnymi zmianami. Można przypuszczać, że wahania w liczebności tej kategorii wynikają w dużej mierze $\mathrm{z}$ pewnej niekonsekwencji w procesie wydawniczym (wydawnictwa niechętnie realizują obowiązek egzemplarza obowiązkowego będącego podstawą obliczeń statystycznych). Łącznie w latach 2010-2017 wydano 3079 tytułów, co stanowi średnio 384 tytułów rocznie. Najmniej (288 tytułów) wydano w 2012 r., zaś rekordową wartość liczby tytułów osiagnięto w 2011 r. (464). Ten zauważalny znaczny wzrost, zwłaszcza w odniesieniu do roku 2010, można uznać za wynik mody zapoczątkowanej przez Stephenie Meyer: „do [...] wampirów bardzo szybko dołączyły wilkołaki, a następnie wyklęci i upadłe anioły [...] W ciagu kilkunastu miesięcy do księgarń trafiły setki tytułów, których fabuła powstawała według pewnego sprawdzonego wzorca" (Gołębiewski \& Waszczyk, 2012, s. 137). Z kolei spadek w 2012 r. jest naturalna konsekwencją braku interesujących propozycji oraz trudnością w zdobyciu nowych licencji. Na szczęście po następujących spadkach (w 2012 i 2015 r.) obserwujemy trwały trend wzrostowy - wydawcy konsekwentnie i niezłomnie próbują zbudować ciekawą ofertę wydawniczą dla tej grupy czytelników. W ciagu ostatnich trzech lat przybyło w sumie 1199 publikacji, czyli liczona $\mathrm{w}$ tytułach produkcja wydawnicza zwiększyła się o 38\%. Wydaje się, że trend ten nie jest zjawiskiem wyjątkowym ani zaskakującym i można wpisać go w szerszą tendencję wzrostową całego rynku książki, 
charakterystyczną dla wszystkich krajów Unii Europejskiej. Można go łatwo wytłumaczyć po pierwsze - charakterystyczną dla współczesnej ekonomii tendencją do wzbogacania i różnicowania oferty rynkowej, a po drugie - intensywnym rozwojem i zmianami w technikach edytorskich znacznie upraszczających proces wydawniczy oraz skracających czas, jak i koszty przygotowania pojedynczego tytułu (np. druk cyfrowy, rozwój self-publishingu, wydawnictwa typu vanity press). Poszerzaniu oferty tytułów (określanej często jako nadprodukcję lub inflację tytułów) towarzyszy rażący spadek nakładów. Co gorsza zwiększająca się liczba tytułów nie koreluje ze wzrostem liczby sprzedanych egzemplarzy oraz przychodami osiaganymi na rynku książki, które z roku na rok osiagają coraz niższe wartości. Według szacunków segment rynku książki dla młodzieży odnotowuje z roku na rok konsekwentny spadek przychodów: w 2010 r. - $73 \mathrm{mln}$, w 2011 - $41 \mathrm{mln}$, w 2012 - $35 \mathrm{mln}$, w 2013 - 33 mln, w 2014 - 34 mln (Gołębiewski \& Waszczyk, 2015, s. 159).

Interesującym trendem w przypadku literatury młodzieżowej jest przewaga tłumaczeń nad książkami wydawanymi przez rodzimych twórców - trend ten ma charakter stały i w ciagu ostatnich 5 lat wynosił do kilku do kilkudziesięciu procent.

Tab. 2. Produkcja wydawnicza książek dla młodzieży w latach 2010-2017

\begin{tabular}{|c|c|c|c|c|}
\hline Rok & $\begin{array}{c}\text { Liczba } \\
\text { wydanych } \\
\text { tytułów }\end{array}$ & $\begin{array}{c}\text { Udział } \\
\text { procentowy } \\
\text { w rynku książki }\end{array}$ & $\begin{array}{c}\text { Wydania } \\
\text { w języku } \\
\text { polskim }\end{array}$ & $\begin{array}{c}\text { Wydania } \\
\text { w języku } \\
\text { obcym }\end{array}$ \\
\hline 2010 & 324 & $1,09 \%$ & $43 \%$ & $57 \%$ \\
\hline 2011 & 464 & $1,4 \%$ & $42 \%$ & $58 \%$ \\
\hline 2012 & 288 & $0,8 \%$ & $37 \%$ & $63 \%$ \\
\hline 2013 & 398 & $1,2 \%$ & $44 \%$ & $56 \%$ \\
\hline 2014 & 406 & $1,24 \%$ & $48 \%$ & $52 \%$ \\
\hline 2015 & 353 & $1,05 \%$ & $44 \%$ & $55 \%$ \\
\hline 2016 & 446 & $1 \%$ & $38 \%$ & $62 \%$ \\
\hline 2017 & 400 & $1,10 \%$ & $47 \%$ & $53 \%$ \\
\hline
\end{tabular}

Źródło: opracowanie własne na podstawie „Ruch Wydawniczy w Liczbach” 2010-2017

Ta część piśmiennictwa charakteryzuje się więc nieznaczną przewaga twórczości obcojęzycznej. Zdecydowana większość tłumaczeń pochodzi 
z języka angielskiego (ok. 74\% wszystkich tłumaczeń). Znacznie rzadsze są przekłady z języka francuskiego (6\%), hiszpańskiego (5\%), niemieckiego (4\%), włoskiego (4\%), japońskiego (4\%) i szwedzkiego (3\%) (za „Ruch Wydawniczy w Liczbach" 2010-2017).

\section{Wydawcy}

L Łatwo zauważyć, że zdecydowaną większość tytułów z tego rynku publikują komercyjne wydawnictwa profesjonalne (średnia $z$ danych na podstawie „Ruchu Wydawniczego w Liczbach”: 83\%), a więc takie firmy komercyjne, dla których działalność wydawnicza jest głównym lub jednym z głównych obszarów działalności. Firmy te wyraźnie wpisują się w pewną tradycję edytorska, w ramach której szczególną uwagę zwraca się na formalno-estetyczne aspekty działalności, dzięki czemu ich produkcja zyskuje na wartości. Nie tylko starannie dobieraja tytuły do swojej kolekcji, ale rzetelnie selekcjonuja nadesłane do publikacji teksty, zapewniając odpowiednią redakcję i korektę, a następnie publikuja je na własne ryzyko finansowe. Dominacja wydawców profesjonalnych zapewnia odpowiedni poziom prac, dzięki czemu na rynku pojawia się niewiele książek wydanych przez autora w ramach różnych form self-publishingu. Z założenia powinno to być gwarancja, iż prezentowane dzieła zawierają różnorodne wartości (np. poznawcze, wychowawcze, artystyczne), które mają kształtować odpowiednie postawy młodego czytelnika. Niestety dzisiejszą ofertą wydawniczą rządzą bezlitosne prawa rynku, a zwłaszcza prawo popytu, które sprawia, że na rynku pojawiają się często ksiazżki nastawione jedynie na sukces komercyjny, pozbawione wartości ideowych, a nawet kurioza, które trudno nazwać książkami (jak np. pozycje autorstwa Keri Smith, takie jak Zniszcz ten driennik Grupy Wydawniczej K.E. Liber czy To nie ksiazk $k a$ wydane przez wydawnictwo Novae Res. Warto także wspomnieć o rodzimym odpowiedniku wydawnictwa Kaktus w postaci Ksiqżki pod tytułem Roberta Trojanowskiego.

Do grupy największych wydawców literatury młodzieżowej należą tak renomowane oficyny, jak: Wydawnictwo Olesiejuk, Wydawnictwo Media Rodzina, Wydawnictwo Jaguar, Nasza Księgarnia, Akapit Press, Amber, Novae Res, Zielona Sowa, Egmont, Publicat, Społeczny Instytut Wydawniczy Znak, Galeria Książki, Grupa Wydawnicza Foksal, Wydawnictwo Literatura, Wydawnictwo Otwarte, Wydawnictwo Ibis, Edipresse, GWF, Kotori, Pascal, Media Rodzina, Siedmioróg, Wilga, Grupa MAC (za: „Ruch Wydawniczy w Liczbach” 2010-2017). Cieszy zwłaszcza obecność Naszej Księgarni, najbardziej zasłużonego seniora polskiej książki dziecięcej i młodzieżowej. Wśród tej grupy mamy zatem i wydawnictwa specjalizujące się w wydawaniu 
tylko tego typu literatury (np. Egmont, Zielona Sowa, Siedmioróg), jak i takie, dla których książki dla młodzieży stanowią tylko część oferty wydawniczej (np. Amber, Novae Res).

Warto także zauważyć, że wśród wydawców publikujących największą liczbę książek dla młodzieży wyróżniamy dwie grupy: takich, którzy publikuja wyłącznie lub niemal wyłącznie utwory polskich autorów (np. Novae Res, Literatura, Edipresse, Akapit Press, Ridero, Warszawska Firma Wydawnicza, Nasza Księgarnia) oraz tych, którzy zdecydowanie zorientowani są na tłumaczenia (np. Jaguar, Kotori, Pascal, Wydawnictwo JK, Zielona Sowa, Jamakasz, Media Rodzina, GWF, Publicat, Wydawnictwo Otwarte, Egmont, Amber).

\section{Tematyka, autorzy, trendy}

L W analizowanym okresie mamy do czynienia z kilkoma interesującymi zjawiskami odnośnie do poszczególnych autorów i tytułów, choć trudno mówić o zdecydowanych, wyrazistych liderach. Ponieważ wciąż brak jednej, rzetelnej i opartej na wynikach sprzedaży listy najpopularniejszych tytułów, w zakresie analizy tematycznej odwołujemy się do analiz firmy GfK Polonia ${ }^{4}$, rankingu bestsellerów „Magazynu Literackiego KSIAZŻKI”, zestawień miesięcznych „Gazety Wyborczej” oraz raportów Biblioteki Analiz z interesującego nas okresu. Dokonując analizy tematyki literatury dla młodzieży, wspomnieć należy o kilku najważniejszych zjawiskach tego sektora rynku książki:

- Zaskakująca popularność książek o tematyce wampirycznej, które niejako wypełniły lukę po Harrym Potterze. Czterotomowy cykl Stephenie Meyer Zmierzch (tj. Zmierąch, Księ̇yc w nowiu, Zaćmienie, Przed świtem) opowiadający o miłości wampira Edwarda i Belli, choć debiutował w Polsce w 2007 r. stale budzi sympatię czytelników i zajmuje wysokie pozycje na listach bestsellerów. W tym samym nurcie pozostaja takie prace jak: cykl Monster High (Upiorna sqkoła, Upiór z sasiedztwa, O wilku mowa, Po moim trupie, Zabójczo stylowy notes) Lisi Harrison o upiornych potworach oraz aż dwunastotomowy cykl Osaczona stworzony przez Kristin Cast oraz jej matkę Phyllis Christiane Cast o amerykańskich nastolatkach naznaczonych wampiryzmem. I choć od 2014 r. prorokuje się, m.in. na łamach „The Pu-

\footnotetext{
${ }^{4}$ Analizy te opracowane są na podstawie danych z sieci punktów sprzedaży detalicznej, która jest reprezentatywna dla całego rynku na poziomie od 40\% do $70 \%$ (Gołębiewski \& Waszczyk, 2016, s. 35).

${ }^{5}$ To najstarsze zestawienie najpopularniejszych tytułów książkowych opierające się na deklaracjach firm detalicznych sieci Empik i Matras oraz regionalnych Domów Książki, a więc tylko pośrednio odzwierciedla wyniki sprzedaży.
} 
blishers Weekly" (za: Zając, 2014, s. 2), odejście od nieautentycznej, fikcyjnej i sztucznej rzeczywistości przeróżnych dystopii, urbanofantastyk czy fantastyk, to paradoksalnie młodzi czytelnicy zasadniczo nie realizują tych wizji, gdyż wciąż preferują nierzeczywistość świata przedstawionego w swoich wyborach lekturowych. Ogromnym zainteresowaniem młodzieży cieszą się publikacje, w których główną rolę odgrywaja „,nie tylko wampiry, ale także wilkołaki, nieumarli, upadłe anioły i wszelkiej maści demony" (Gołębiewski \& Waszczyk, 2012, s. 132). Martwi to znawców tematu, którzy piszą, iż „ogląd półek polskich ksiegarń (i list bestellerów) wprowadza więc w konfuzję. $\mathrm{Na}$ półkach bowiem wampiry, wilkołaki, elfy, krasnoludy, bogowie i demony, dzieciaki brodzą w postapokaliptycznej poświacie" (Zając, 2014, s. 2). Wydaje się, że tego typu fikcja będąca w opozycji do rzeczywistości dnia codziennego jest dla nastolatków atrakcyjniejsza, zaś powszechne utożsamienie nierzeczywistości z niedojrzałością czytelników wynika w głównej mierze z nieprzyjemnych, alienujących doświadczeń dnia codziennego nastolatków, którzy dopiero próbuja odnaleźć swoje prawdziwe Ja. Nie dziwi zatem popularność trzynastotomowego cyklu powieści fantasy Zwiadowcy australijskiego pisarza Johnna Flanganna, który stworzył popularną serię przygód nastoletniego Willa i jego przyjaciół, czy cykl Igrayska śmierci Suzanne Collins, który jest dość ponurą opowieścią o przyszłości Ameryki.

- Niezrozumiała dla wielu popularność powieści fantasy oraz nieustające zainteresowanie Harrym Potterem. Po prawie dwudziestu latach po publikacji pierwszego tomu ekscytacja losami młodego czarodzieja nie ustaje. $\mathrm{Na}$ fali tego zainteresowania wydawnictwo Media Rodzina zdecydowało się na reedycję pierwszego tomu - bogato ilustrowana przez Jima Kay’a, która wdarła się przebojem na listy bestsellerów 2015/2016 r., dystansując pozostałe propozycje. Trend ten stale jest umiejętnie podtrzymywany przez wydawcę, mimo że powrót potteromanii był przez niego kontestowany $z$ pewnym zdziwieniem: ,zaskoczeniem dla nas był jednak fakt, że siła marki »Harry Potter« jest tak wielka, że - jak się okazało - gdyby tom ten autorka napisała wierszem, to też byłby bestsellerem! Któż by przypuszczał, że niezbyt dzisiaj rynkowo hołubiony gatunek, jakim jest dramat, nie będzie tu żadną przeszkodą" (za: Zając, 2017, s. 1). Mowa tu oczywiście o wydanym w pierwszej połowie 2016 r. Harrym Potterze i prz̨ekletym dziecku, dwuczęściowej sztuce teatralnej napisanej przez Jacka Thorne'a na podstawie historii J.K. Rowling, której nakład osiagnął 530 tys. egzemplarzy. 
- Prorokowany przez wielu zwrot ku powieści realistycznej opisującej najtrudniejsze problemy dnia codziennego młodzieży. Był to początkowo nurt poboczny, dla wielu wręcz obojętny. Bez żadnej przesady można powiedzieć, że prawie przeszedł on niezauważony, skoro dwa kultowe tytuły z tej tematyki, odnoszące gigantyczne sukcesy w USA i na zachodzie i osiagające milionowe nakłady, w Polsce plasowały się gdzieś w środku list bestsellerów pomimo towarzyszących im filmowym ekranizacjom ze znanymi aktorami. Przykładem jest tu powieść Johna Greena Gwiazd naszych wina opowiadająca o wzruszającej historii miłości chorych na nowotwór nastolatków czy Charlie Stephana Chbosky'ego - napisana w formie listów opowieść o pierwszych miłosnych doświadczeniach, relacjach w rodzinie, narkotykach oraz potrzebie akceptacji. W tym kręgu pozostaje też kolejna powieść Greena Papierowe miasta - powieść o dojrzewaniu, prawdziwej przyjaźni i miłości oraz powieści Gayle Formann (Zostań, jeśli kochasz i Wróć, jeśli pamiętasz) o potędze miłości i wyborach, których musimy dokonywać. I choć wspomniane tytuły znajdują się na listach najlepiej sprzedających się książek, osiagając przyzwoite wyniki (średnio 40-79 tys. egz. według danych „Ruchu Wydawniczego w Liczabach" 2010-2017), to ich umiarkowany sukces utwierdza tylko w przekonaniu, że dopiero od 2014 r. możemy mówić o zmianie preferencji czytelniczych i powrocie do czytelniczych łask powieści realistycznej o tematyce obyczajowej.

- Nieprzemijająca moda na tzw. nie-książki i kolorowanki. Są one określane mianem gimnazjalnych pseudoksiążek i stanowią bardzo złożone zagadnienie. Mowa tu o budzącej kontrowersje, acz pozostającej wysoko na liście bestsellerów książce Znisærz ten driennik Keri Smith i jej pochodnych, czy Tajemniczy ogród i Zaczarowany las Johanna Basforda. Wielotysięczne nakłady i zamieszanie, jakie pozycje te wywołały na rynku wydawnictw dla młodzieży sprawiły, że wydawcy otwarcie przyznali, iż są zaskoczeni tym niewytłumaczalnym i niezrozumiałym sukcesem publikacji, których nie sposób scharakteryzować za pomoca standardowych kategorii literaturoznawczych (teoretycznych, genologicznych czy estetycznych), stąd konieczne jest poszerzenie albo znaczna modyfikacja definicji książki, gdyż doszło do radykalnego przewartościowania dotychczas wzorców. Sukces tego typu projektów, w których mamy do czynienia z elementami kreatywnymi, pozwalającymi na swobodną ingerencję czytelnika w treść, wręcz zachęcającymi do najdzikszych eksperymentów sprawił, iż analitycy rynku zaniepokojeni pytają: „Czy to dowód kompletnego zidio- 
cenia czytelników, owczego pędu czy też rzeczywiście końca kultury narracji na rzecz fragmentów, ilustracji, czy [...] kreatywnej destrukcji”' (Gołębiewski, 2015).

- Utwory nawiązujące do sentymentów rodziców dzisiejszych nastolatków (ok. 40-50 lat). Są to książki z tzw. nurtu sentymentalnego, które wydają się być jeszcze większym zaskoczeniem niż poprzednie kategorie. Tego typu książki stanowią ok. 17\% literatury dla młodzieży, z czego 11\% dotyczy pisarzy z XX w. (np. Lucy Maud Montgomery, Antoine de Saint-Exupery, Zbigniew Nienacki, Edmund Niziurski), a pozostałe 6\% dotyczy klasyków literatury młodzieżowej (Juliusz Verne, Aleksander Dumas, Marek Twain, Daniel Defoe, Robert Louis Stevenson). Popularność Ani z. Wyspy Księcia Edwarda ostatniego tomu sagi Lucy Maud Montgomery, kolejnych tomów „Jeżycjady" Małgorzaty Musierowicz (Feblik, MacDusia, Wnuczka do orzechów) czy Tomka w krainie kangurów Alfreda Szklarskiego dziwi tym bardziej, że są to pozycje dość chłodno przyjęte przez współczesna krytykę literacką. I choć opinie krytyków są raczej mocno naznaczone ironicznością i naganą odnośnie do ich poetyki, nierzadko kwestionuja otwarcie wszelkie powody ulegania ich urokom, ważniejsze jest jednak to, że czytelników, a raczej czytelniczki, to nie zraża. Okazuje się, że prace te wciąż sa atrakcyjne dla sporej grupy i posiadają moc przyciagania nowych czytelników, o czym najlepiej świadczą ich nakłady oscylujące w granicach 60 tys. (za: „Ruch Wydawniczy w Liczbach" 2010-2017).

- Zainteresowanie nastoletnich czytelników beletrystyki wszelkiego rodzaju cyklami, seriami czy też sagami, a więc wszelkiego rodzaju powieściami, których kolejne tomy publikowane są w pewnych odcinkach czasu, a każdy z nich stanowi całość, często komponowaną osobno, z własnym punktem kulminacyjnym. Jakkolwiek byłyby negatywne opinie krytyków, nie da się nie zauważyć, że tego rodzaju literatura cieszy się szczególną atencją młodzieży. Towarzysząca kolejnym tomom globalna promocja medialna tylko potęguje zainteresowanie nastolatków, którzy skłaniają się ku lekturom będącym wielokulturowym wydarzeniem. Sukces sagi Zmierz̨ch, cyklu Zwiadowcy czy serii Percy Jackson i bogowie olimpijscy zachęca wydawców do sięgania po licencje na tego typu publikacje, zwłaszcza gdy towarzyszą im nie tylko fenomenalne, gigantyczne reklamy o zasięgu globalnym, ale także ekranizacje kinowe, gry komputerowe lub inne formy aktywizacji czytelniczej (np. oficjalna witryna lub profil w mediach społecznościowych). To właśnie wtedy nagle pojawia się 
bohater, którym interesują się rzesze nastoletnich czytelników. W ślad za tym medialnym zamieszaniem pojawiaja się wielotysięczne nakłady, swoista moda, a nawet histeria - pojawia się przymus własności czy też posiadania kolejnych tomów oraz porzucenia dotychczas atrakcyjniejszych form spędzania wolnego czasu.

\section{Publikacje niedrukowane: e-booki, audiobooki}

L Z uwagi na to, że przedmiotem naszego zainteresowania jest młodzież określana mianem cyfrowej, to z określenia tego powinna wynikać sugestia, że rynek książki powinien być przygotowany na tego typu klienta i oferować mu atrakcyjną ofertę książek w formie audio lub elektronicznej. Niestety „cyfrowa oferta książek [dla młodzieży - przypis S.B.] prezentuje się co najwyżej skromnie" (Gołębiewski \& Waszczyk, 2014, s. 153), choć rynek e-booków dla dorosłych od 2010 r. rozwija się w Polsce bardzo dynamicznie. To właśnie wtedy firma Virtualo, specjalizująca się w rozwiązaniach IT do sprzedaży e-booków, została zakupiona przez Empik, który postanowił rozwijać rynek książki elektronicznej. Decyzja ta wynikała najprawdopodobniej z prognozowanych wówczas przewidywań, że rynek e-booków będzie rozwijał się niezwykle dynamicznie $z$ uwagi na zmieniające się decyzje konsumentów, cenę oraz łatwość użytkowania. Także analizy i raporty napawały optymizmem, np. w latach 2010-2012 odnotowano aż trzycyfrowy wzrost sprzedaży.

Niestety prognozy te zupełnie zawiodly w odniesieniu do segmentu książki młodzieżowej, w którym dominują wciąż książki w tradycyjnej formie. Jak przyznaje M. Zając

analiza „niedrukowanych” sektorów publikacji związanych z rynkiem książki dla niedorosłych [...] nie nastraja optymistycznie. Jeszcze rok temu wyrażałem [...] nadzieję na szybki rozwój formatów audio/elektronicznych. Niestety, wydaje się, że przedwczesny był to optymizm" (2014, s. 4).

Przyczyn tego stanu rzeczy należy upatrywać m.in. w przywiązaniu wydawców do tradycyjnej formy i niechęci do eksperymentowania z właściwymi formatami zapisu (ePub, Mobipocket), obawach przed nieuprawnionym dostępem (piractwem), szukaniu sposobów właściwego zabezpieczenia plików oraz wysokiej 23\% stawce Vat ${ }^{6}$. Nie dziwi zatem, że oferta audio- i e-booków jest nikła i wydaje się ogromnym rozczarowaniem. Spośród wydawców posiadających w swojej ofercie takie formaty dla młodzieży można wymienić: Olesiejuk - 70 tytułów audio, Ayzmut - 89 tytułów audio, Woblink - 450 e-booków (łącznie dla dzieci i młodzieży), empik - 456 e-booków

${ }^{6}$ E-booki i appsy w całej Unii Europejskiej są opodatkowane 23\% podatkiem jako usługa. 
(łącznie dla dzieci i młodzieży), Audioteka.pl - 171 tytułów audio, Virtualo - 470 e-booków, Nexto - 733 e-booków (łącznie dla dzieci i młodzieży), Nasza Księgarnia - 100 e-boków (Zając, 2014, s. 4). Wiemy także, że e-booki posiadaja w swojej ofercie takie firmy jak: W.A.B, Znak, Skrzat, Siedmioróg.

Trudno nie zgodzić się z opinią, że nie są to liczby powalające, zwłaszcza jeśli odniesiemy je do generacji typowo cyfrowej. Wygląda na to, że ominęła nas ogólnoświatowa histeria e-bookowa, a wydawcy dopiero testują ten segment rynku i nie są do końca przekonani do inwestycji w tego typu publikowanie. Sa i tacy wydawcy, jak np. Egmont i Media Service Zawada, którzy po etapie prób i spadku sprzedaży e-booków wycofali się z produktów na urządzenia mobilne. Zaskakujący jest także fakt, że w analizowanym okresie nie przygotowano żadnych appsów na urządzenia mobilne dla młodziė̇y, choć wiara w siłę „book apps” jako produktu idealnego, ,skrojonego na miarę” dla cyfrowej generacji była ogromna .

\section{Nagrody oraz targi}

L Warto też zwrócić uwagę na przyznawane cyklicznie twórcom nagrody i wyróżnienia, które w pośredni sposób potęgują zainteresowanie określonym tytułem. Spośród wielu konkursów literackich w dziedzinie literatury największym uznaniem cieszy się konkurs Książki Roku Polskiej Sekcji IBBY, którego głównym celem jest promocja wartościowej literacko i artystycznie książki. W kategorii książki dla młodzieży w interesujących nas latach nagrodzono: Omege Marcina Szczygielskiego (2010), Jajko księ̇yca Zofii Beszczyńskiej z ilustracjami Natalii Talarek (2011), Oro Marcela A. Marcela (2012), Most nad Missisipi Ewy Przybylskiej (2013), Franciszka Anny Piwkowskiej (2014), 5 sekund do IO Małgorzaty Wardy (2015), Rutka Joanny Fabickiej (2016), Serce Neftydy Marcina Szczygielskiego (2017). Pozostałe konkursy niestety znacząco faworyzują książkę dla dzieci młodszych. Na mocy tej prawidłowości konkursy: Empiku na Najlepszą Książkę Dziecięcą „Przecinek i Kropka”, Polskiego Towarzystwa Wydawców Książek na Najpiękniejszą Książkę Roku, czy Ogólnopolski Konkurs „Dobre Strony” będący elementem wrocławskich Targów Książki dla Dzieci i Młodzieży są w zasadzie skierowane do twórców (autorów, ilustratorów) książki dla młodszych czytelników (do 10 lat). Podobnie ma się rzecz z nagrodami literackimi, m.in. Nagroda im. Kornela Makuszyńskiego, Literacką Nagrodą Zielonej Gąski, PEGAZIKIEM, Mądrą Książką

\footnotetext{
7 W Polsce zrealizowano co prawda kilka udanych projektów na iPadowe i iPhonowe urządzenia, jak choćby świetna Lokomotywa firmy Big Rabbit czy produkty firmy Festina Lente, ale są to wszystko propozycje dla młodszych czytelników (do 10 r.ż.).
} 
Roku, Nagrodą Literacką m. st. Warszawy, a nawet plebiscytem dla wydawców Dong, gdzie ocenia się w zasadzie zwykle ambitną książkę dziecięca. Dzieje się tak głównie z powodu braku rozgraniczenia i rozróżnienia pomiędzy dwiema kategoriami i ujmowania jej łącznie jako literatura dla dzieci i młodzieży, a także z uwagi na zalew i nadprodukcję nowych tytułów książki dziecięcej.

$\mathrm{Na}$ zainteresowanie poszczególnymi tytułami oraz sukces ekonomiczny wydawcy ogromny wpływ maja z pewnością także cyklicznie organizowane targi książki, gdzie prezentowane są najświeższe i najnowsze wydawnictwa. Najważniejsze, o których warto wspomnieć, to Poznańskie Targi Książki PEGAZIK, wrocławskie Targi Książki dla Dzieci i Młodzieży Dobre Strony, warszawski Festiwal Książki dla Dzieci i Młodzieży „Czytajmy” oraz Festiwal Literatury dla Dzieci w ramach Warszawskich Targów Książki, a także Targi Książki dla Dzieci w ramach krakowskich Targów Książki. Wszystkie wspomniane imprezy maja jeden wspólny cel: wychować pokolenie świadomych oraz aktywnych czytelników ciekawej, ważnej oraz wartościowej książki dziecięcej i młodzieżowej.

\section{Czytelnictwo}

Wiele zdaje się wskazywać na to, że niebagatelnym problemem dla wydawców jest coraz powszechniejsze zanikanie praktyk czytelniczych oraz wybieranie innych, bardziej atrakcyjnych form spędzania wolnego czasu (komputer, telewizor). Jak donoszą coroczne raporty Biblioteki Narodowej o stanie czytelnictwa, aż 1/5 nastolatków, w tym głównie chłopcy, znajduje się poza kulturą pisma: nie tylko nie czytają oni regularnie dłuższych tekstów, ale także nie sięgaja do książek ani gazet choćby raz do roku (Koryś, Michalak \& Chymkowski, 2015, s. 31). Mamy więc do czynienia nie tylko z pogłębiającym się $z$ roku na rok spadkiem czytelnictwa, ale także pogłębiającym się upadkiem kulturowym, czy wręcz cywilizacyjnym. Obowiązki szkolne, liczne zajęcia pozalekcyjne oraz organizacja czasu wolnego, w którym na plan pierwszy wysuwa się oglądanie telewizji (także na ekranie komputera), a zwłaszcza filmów (seriali) oraz gry komputerowe, sporty, a także coraz popularniejsze życie online na portalach społecznościowych (Facebook, Snapchat, Instagram) wypierają skutecznie proces lektury z życia codziennego nastolatków. Co gorsza coraz śmielej i bez skrępowania sami zainteresowani podnosza, że czytają tylko i wyłącznie w ramach obowiązku szkolnego, a kiedy ten ustaje, przestaja po prostu sięgać po książki (w 2010 - zaledwie 10\%, w 2015 - 31\%). Generalnie nieczytajacy $(48 \%)$ oraz nieczytający książek (5\%) to razem ponad połowa wszystkich nastolatków w wieku 15 lat i więcej (Koryś, Kopeć, Zasacka 
\& Chymkowski, 2016, s. 22). Te zatrważające wyniki potwierdzają badania Zofii Zasackiej przeprowadzone na zlecenie Instytutu Badań Edukacji (2014) oraz raporty PIK. Nie ma chyba żadnych watpliwości, że ta niepokojąca tendencja odchodzenia od książek powinna w sposób radykalny wpłynąć na dokonywane przez wydawców wybory i działania, które powinny być ukierunkowane na atrakcyjną i różnorodną ofertę odpowiadającą zainteresowaniom młodych ludzi.

\section{Podsumowanie}

L W tym miejscu sformułujemy kilka uwag o charakterze generalizującym. W analizowanym okresie mamy do czynienia z wieloma zmianami, zarówno jakościowymi, jak i ilościowymi w interesującym nas segmencie rynku książki, z których bodajże za najważniejszą uznamy niebywała różnorodność oferty adresowanej do czytelników. Jak przyznaje z dumą Anna Wiśniewska z Wydawnictwa Olesiejuk, „każdy potencjalny czytelnik znajdzie coś odpowiedniego" (za: Zając 2017, s. 2). W najbliższych latach możemy z pewnością spodziewać się dalszego wzrostu liczby publikowanych tytułów, rosnącego udziału pierwszych wydań, jednak przy dalszym spadku średniego nakładu.

Obserwowane na przestrzeni lat poważne spadki sprzedaży (o 54\%) oraz wartości segmentu (spadek o 24\%) są wynikiem luki po intratnych autorach oraz „mega bestsellerowych” tytułach. Obecne działania wydawców determinuje brak nowych liderów, pomysłów i ciekawych bestsellerów, albowiem „nie widać nowych kandydatów do panteonu” (Zając, 2011, s. 1). Braki te wydawcy próbują zastapić większą liczbą tytułów, które rozchodzą się jednak w zdecydowanie mniejszym nakładzie (20-10 tys. egzemplarzy).

W zakresie tematyki trudno prorokować trendy i przewidywać zainteresowanie nabywców. Pojawiające się od 2010 r. setki tytułów (głównie fantasy oraz paranormal), których fabuła powstaje według sprawdzonego, bardzo konwencjonalnego scenariusza (akcja dzieje się w jakiejś nieokreślonej przeszłości lub świecie alternatywnym, a tematem głównym są często wędrówki bohaterów lub poszukiwanie samoświadomości), pełna nieprzejrzystych, niejednoznacznych i nieprzewidywalnych postaci (wampiry, „wyklęci”, „upadłe anioły"), bez motywacji psychologicznej, często bez introspekcji, miały szybko się wyeksploatować i ustapić miejsca prozie realistycznej i psychologicznej, mocno osadzonej w realiach dnia codziennego i skoncentrowanej na sferze przeżyć wewnętrznych oraz analizie psychologicznej głównych bohaterów. Młodzi czytelnicy zdyskontowali jednak zamierzenia oraz plany wydawców i w poszukiwaniu własnej tożsamości dalej chętnie zatapiają się w świat prozy z gatunku paranormal, fantasy, science-fiction czy powieści grozy. Widocznie 
potrzeba znalezienia własnego $J a$ pozornie dojrzałych nastolatków wymaga fantastyki i anormalności, a wydawcy chętnie i szybko reaguja na te potrzeby, zapewniając w swojej ofercie takie tytuły, które stylistyką i fabułą nawiązuja do wcześniej wspomnianych gatunków. Na nic się tu zdadzą głosy sprzeciwu komentatorów tego typu lektur, bowiem od lat obserwujemy na rynku książki wzrost sprzedaży publikacji z segmentu non-fiction oraz spadek sprzedaży powieści obyczajowej (Gołębiewski \& Waszczyk, 2015). Wydaje się, że rację mają R.A. Peterson i R.M. Kern pisząc, iż osoby nieposiadające wysokiego kapitału kulturowego ograniczaja się do najbardziej popularnych gatunków i najłatwiej przyswajalnych treści (1996, s. 907). Poza tym wydaje się, że w chwili obecnej jest to jedyny sposób na utrzymanie w ryzach galopującego w tempie zastraszającym spadku czytelnictwa: narastająca tendencja do ograniczania aktywności lekturowej oraz wzrost liczby nieczytających powyżej 15 roku życia mogą zostać zahamowane jedynie przez swobodny dostęp do atrakcyjnej z ich punktu widzenia oferty lekturowej (papierowej i elektronicznej).

Sposobem na zatrzymanie nastoletniego czytelnika może być ukierunkowana, atrakcyjna oferta wydawnicza dostosowana do jego zainteresowań i problemów. Interesująca fabuła, prosty język, nieskomplikowana akcja oraz stylistyka nawiązująca do ulubionych gatunków sprawiają, że młodzież porzuca swoje ulubione czynności na rzecz lektury. Ważne, aby oprócz jednorazowego zainteresowania, przyciagnać ich na trochę dłużej, do czego idealnie nadają się serie wydawnicze czy wielotomowe sagi. Ostatnie lata pokazują, że wiele sag czy cykli spełniło swoje zadanie. Handlowy wynik np. Dziedzictwa Christophera Paoliniego, napawa pewnym optymizmem, gdyż wskazuje, iż młodzież w nielicznych przypadkach sięga po lekturę i daje się na dłużej związać $z$ ulubionym autorem $\mathrm{i}$ jego bohaterem.

Ogromne znaczenie mają tzw. mody czytelnicze, dlatego wydawcy muszą pamiętać, że o handlowym sukcesie poszczególnych tytułów decydują czynniki często nieprzewidywalne, takie jak np. opinie w mediach społecznościowych. Tylko ta książka, która stała się wydarzeniem, i to nie literackim, a masowym, wielomedialnym ma szansę zdobyć uwagę i czas nastolatków.

Literatura młodzieżowa, jako atrakcyjnym rynkiem, zaczynają się interesować coraz liczniejsze oficyny, mniej lub w ogóle wcześniej nieznane na tym rynku (np. Hachette Polska, Egmont, Sonia Draga czy chociażby Bellona itp.). Z kolei wydawcy od lat działający na rynku śmiało dokonują restrukturyzacji, porządków organizacyjnych oraz zmian personalnych w działach wydawniczych i handlowych, po to, aby dostosować struktury, procesy i obsady do ambitnych celów i realizacji nowych zadań związanych z przygotowaniem atrakcyjnej oferty dla nastoletnich czytelników. 
Zauważalny jest także wzrost i rozwój inicjatyw targowych sprofilowanych pod katem nastoletniego czytelnika. Obserwowany z roku na rok zarówno wzrost reprezentacji wydawców, jak i liczby poszczególnych imprez wynika z faktu przywiązywania coraz większej uwagi do konieczności pozyskania nowych czytelników, na których typowe formy promocji książek zdaja się nie działać. Stąd coraz śmielsze i atrakcyjniejsze oferty oraz inicjatywy przygotowywane przez wydawców.

\section{Bibliografia}

Gołębiewski, Lukasz (2015). Bestseller Keri Smith. Biblioteka Analiz, $5,3$.

Gołębiewski, Łukasz, Frołow, Kuba \& Waszczyk, Paweł (2010). Rynek ksiażki w Polsce 2010. Wydawnictwa. Warszawa: Biblioteka Analiz.

Gołębiewski, Łukasz, Frołow, Kuba \& Waszczyk, Paweł (2011). Rynek ksiażki w Polsce 2011. Wydawnictwa. Warszawa: Biblioteka Analiz.

Gołębiewski, Łukasz \& Waszczyk, Paweł (2012). Rynek ksiażki w Polsce 2012. Wydawnictwa. Warszawa: Biblioteka Analiz.

Gołębiewski, Łukasz \& Waszczyk, Paweł (2013). Rynek ksiażki w Polsce 2013. Wydawnictwa. Warszawa: Biblioteka Analiz.

Gołębiewski, Łukasz \& Waszczyk, Paweł (2014). Rynek ksiażki w Polsce 2014. Wydawnictwa. Warszawa: Biblioteka Analiz.

Gołębiewski, Łukasz \& Waszczyk, Paweł (2015). Rynek ksiażki w Polsce 2015. Wydawnictwa. Warszawa, Biblioteka Analiz.

Gołębiewski, Łukasz \& Waszczyk, Paweł (2016). Rynek ksiażki w Polsce 2016. Wydawnictwa. Warszawa, Biblioteka Analiz.

Gołębiewski, Łukasz \& Waszczyk, Paweł (2017). Rynek ksiażki w Polsce 2017. Wydawnictwa. Warszawa, Biblioteka Analiz.

Koryś, Izabela, Kopeć, Jarosław, Zasacka, Zofia \& Chymkowski, Roman (2017). Stan czytelnictwa w Polsce w 2016 r. Warszawa: Biblioteka Narodowa.

Koryś, Izabela, Michalak, Dominika \& Chymkowski, Roman (2015). Stan çytelnictwa w Polsce w $2014 r$. Warszawa: Biblioteka Narodowa.

Kozakiewicz, Mikołaj (1998). Młodzież - teorie młodzieży. W: W. Szewczuk (red.), Encyklopedia psychologii. (s. 224-255). Warszawa: Fundacja Innowacja.

Laskowska, Jolanta (2017). Rynek książki dla dzieci i młodzieży w Polsce. Jednak Ksiażki, 7 , 201-209.

Melosik, Zbyszko (2003). Edukacja, młodzież i kultura współczesna. Kilka uwag o teorii i praktyce pedagogicznej. Chowanna, R. XLVI (LIX), 1 (19), 19-37.

Michalak, Dominika, Koryś, Izabela \& Kopeć, Jarosław (2016). Stan caytelnictwa w Polsce w 2015 roku: wstepne wyniki. Warszawa: Biblioteka Narodowa.

Pawliczuk, Witold (2006). Definicje terminu „młodzież” - przegląd koncepcji. Postęy Nauk Medycznych, 6, 311-315.

Peterson, Richard A., Kern, Roger M. (1996). Changing Highbrow Taste: From Snob to Omnivore. American Sociological Review, 61, 5, 900-907.

Peterson, Valerie (2018). Young Adult and New Adult Book Markets. Facts and Figures to Know the Young Adult Book Market Pobrane 15 kwietnia 2019 z: https://www.thebalancecareers.com/the-young-adult-book-market-2799954. 
Ruch Wydawniczy w Liczbach - Polish Publishing in Figures (2010-2017). R. 56-64, ISSN 2083-6953.

Sullivan, Edmund V. (1987). Critical Pedagogy and Television. In: Critical Pedagogy and Cultural Power, ed. D.W. Livingstone. South Hadley (Mass.): Bergin \& Garvey Publishers.

Tobera, Marek (2008). Bibliologia wobec polskiego rynku książki w latach 1944-2007. Przeglad Biblioteczny, 1, 37-66.

Zając, Michał (2012). Bez fajerwerków. Rynek książki dla dzieci i młodzieży. Ksiażki dla Drieci i Mtodrieży, 5(188), 1-4.

Zając, Michał (2014). Stagnacja? Rynek książki dla dzieci i młodzieży. Ksiażki dla Drieci i Mtodziézy, 5(212), 1-4.

Zając, Michał (2016). Spokojniejszy rok? Rynek książki dla dzieci i młodzieży. Ksiażki dla Drieci i Młodzięzy, 5(236), 1-4.

Zając, Michał (2017). W Hogwarcie i w puszczy. Od maja 2016 do maja 2017, czyli rok w książce dla dzieci i młodzieży. Ksiażki dla Dz̧eci i Młodzৃieży, 5(248), 1-4.

Zasacka, Zofia (2014). Czytelnictwo dzieci i mtodzieży. Warszawa: IBE.

\section{Vampires, demons, fallen angels... Book market analysis for teenagers (2010-2017) - selected aspects}

ABSTRACT: In the teenage world, reigned by Facebook, Twitter, Instagram and other social media for years, permanent contacts with reading and books are frequently just incidental, reduced to school reading lists as proven by alarming readership surveys in this age group. On the other hand, however, young fans of the Internet and computer games, intrigued by attractive books, are able to make conscious reading choices and become involved readers. Making the above assumption, an attempt was made at analyzing the book market for teenagers in 2010-2017. Based on data submitted by the Central Statistical Office of Poland, the National Library, Biblioteka Analiz and the Polish Chamber of Books, a quantitative and qualitative analysis of this most demanding, according to $Ł$. Gołębiewski and P. Waszczyk, market was carried out, the mechanisms governing this sector were identified, and also possible corrective measures were indicated aimed at stimulating and shaping permanent reading interests among adolescents.

KEYWORDS: book market, literature for teenagers, quantitative and qualitative analysis of the book market for teenagers 